Previously in this laboratory, experiments similar to that described above, but using double the isotope concentration were performed to determine into which metabolites the ${ }^{14} \mathrm{C}$ had been incorporated. In these experiments the filtrate, after the addition of $\mathrm{NaHCO}_{3}$ and citric acid to remove bicarbonate contamination was evaporated at $50^{\circ} \mathrm{C}$ under reduced pressure to a final volume of approximately $0.5 \mathrm{ml} .10 \mu \mathrm{l}$ aliquots of this solution were applied to $24 \mathrm{~cm}$ circular Whatman No. 1 filter paper and chromatographed horizontally using $n$-butanol, pyridine, water $(3: 2: 1.5)$ as developer. Chromatograms were also made simultaneously of a mixture of known amounts of glucose, fructose, maltose, and sucrose. After development and drying the filter paper was placed on a sheet of 'Industrex type $D$ ' $X$-ray film and kept in the dark at $4^{\circ} \mathrm{C}$ for 14 days. The filter paper was then sprayed with naphthoresorcinol to reveal the sugar zones. On development of the X-ray film it was found that virtually all the

\section{Net Transport of Water and Solutes by an in vitro Rat Intestinal Preparation}

It is well known that through the intestinal wall, as well as through other absorbing epithelial surfaces, water can be transported from lumen to serosa, either without an osmotic gradient 1,2 , as against an activity gradient $2, \mathbf{a}$. This movement of water depends on the presence of glucose, that is to say on the availability of chemical energy $1,3,4$.

The net transport of water is considered by some authors ${ }^{1}$ a process which passively follows the active transport of solutes; while, on the contrary, some others suggest an active transfer presumably by an electrosmotic mechanism ${ }^{2,3}$. The solution which crosses the intestinal wall is an isotonic $\mathrm{Na}$ solution ${ }^{1,4}$ or a more diluted $\mathrm{Na}$ solution, in comparison with that present in the intestinal lumen ${ }^{2}$.

The results here reported (Table) were obtained by using the method described by SMYTH and TAYLOR ${ }^{4}$; the perfusing solution circulates only in the intestinal lumen. Determination of the freezing point and of $\mathrm{Na}$ and glucose contents were carried out on the collected fluids and on circulating solutions.

From our findings it appears that, either by using isotonic circulating solution, or an hypertonic one to which $\mathrm{Na}_{2} \mathrm{SO}_{4}$ has been added, the collected fluid presents in every case a freezing point lower than that of the circulating fluid at the end of the experiment. The freezing points computed from $\mathrm{Na}$ and glucose contents are always higher than those experimentally determined.

Under our experimental conditions, the concentration gradient produced by the transport of solutes can explain the net movement of water without the necessity of in- radioactivity was present in one zone, which corresponded exactly with the sucrose zone on the filter paper.

From these results it is concluded that $\mathrm{CO}_{2}$-fixation in the two dodders tested is a photosynthetic process, and that on a fresh weight basis, the level of photosynthesis in $C$. gronovii and $C$.campestris is similar, and equal to about one tenth the level in Pelargonium leaves.

Zusammenfassung. Die in Cuscuta gronovii und C. Campestris bewiesene Photosynthese ist in ihrem Ausmass in beiden Arten gleichwertig und beträgt ungefähr ein Zehntel desjenigen von Pelargonium-Blättern. Als photosynthetisches Produkt wird in beiden Pflanzen grösstenteils Saccharose festgestellt.

D. MACLEOD

Department of Applied Microbiology and Biology, Royal College of Science and Technology, Glasgow (Great Britain). July 18, 1961.

vocating an electrosmotic mechanism or a STAVERMANN ${ }^{b}$ effect.

Such a gradient could be present also in vivo owing to a low effective blood flow in the intestinal villi because of the counter-current flow in the capillary loops ${ }^{6}$.

Sodium sulphate produces a reduction of the total transported solutes, presumably because of dehydrating and impermeabilizing effect of the salt on the intestinal tissues.

Riassunto. Vengono riportati i dati ottenuti sul passaggio netto di acqua e di soluti attraverso l'intestino isolato di ratto, perfuso con soluzione isotonica o ipertonica per aggiunta di solfato di sodio. E stato determinato anche il $\Delta$ crioscopico dei liquidi raccolti e delle soluzioni di perfusione. Da questi dati appare che il passaggio di acqua dipende dall'istituirsi di un gradiente di concentrazione per il trasporto attivo di soluti nello stesso senso.

Il solfato di sodio eserciterebbe sui tessuti intestinali una azione impermeabilizzante, riducendo cosi il trasporto netto totale di soluti.

S. Rossi and V. CAPraro

Istituto di Fisiologia generale dell'Università di Milano (Italy), July 27, 1961.

1 P. F. Curran, J. gen. Physiol, 43, 1137 (1960). Figure 1 of the mentioned paper presumably was erroneously drawn, the abscissa values having been multiplied by 10 .

2 B. E. Vaughan, Amer. J. Physiol. 198, 1235 (1960).

D. S. Parsons and D. L. Wingate, Blochem. biophys. Acta 30, $666(1958)$.

4 D. H. SMYtK and C, B. TAYLoR, J. Thysiol, 136,632(1957)

5. A. Stavermans, Rec. Trav. chim. Pays-Bas 70, 344 (1951).

- R. W. Berliker, N. G. Levinsky, D. G. DAvidson, and E. MurRAY, Amer. J. Med. 34, 730 (1958),

Small intestine of albino male rat (Wistar strain) weighing $250 \mathrm{~g}$. Length of perfused intestine $30 \mathrm{~cm}$ starting from pylorus, fresh weight $1.52 \pm 0.08 \mathrm{~g}$. Initial quantity of circulating solution $50 \mathrm{ml}$. Time of perfusion $1 \mathrm{~h}$. Temperature of perfusing solution $38^{\circ} \mathrm{C}$. The number of experiments for each group are $6-8$. The mean values \pm S.E. are reported.

\begin{tabular}{|c|c|c|c|c|c|c|c|}
\hline Perfusing solution & $\begin{array}{l}\text { Trans- } \\
\text { ported } \\
\text { solution } \\
\mathrm{ml} / \mathrm{h}\end{array}$ & $\begin{array}{l}\text { Trans- } \\
\text { ported } \\
\mathrm{Na} \\
\mu \mathrm{E} / \mathrm{h}\end{array}$ & $\begin{array}{l}\text { Na con- } \\
\text { centration } \\
\text { in transp. } \\
\text { solution } \\
\mathrm{mE} / 1\end{array}$ & $\begin{array}{l}\text { Trans } \\
\text { ported } \\
\text { glucose } \\
\mu M / \mathrm{h}\end{array}$ & $\begin{array}{l}\text { Glucose } \\
\text { concent. } \\
\text { in transp. } \\
\text { solution } \\
\mathrm{m} M / 1\end{array}$ & $\begin{array}{l}\text { Total } \\
\text { dis- } \\
\text { appeared } \\
\text { glucose } \\
\mu M / h^{s}\end{array}$ & $\begin{array}{l}\text { Freezing points }\left(1 / 100^{\circ} \mathrm{C}\right) \text { of } \\
\text { transported solution and freez- } \\
\text { ing points difference between } \\
\text { transported solution and final } \\
\text { perfusing solution }\end{array}$ \\
\hline $\begin{array}{l}\text { Krebs }+ \text { glucose } \\
13.9 \mathrm{~m} M / 1\end{array}$ & $3.33 \pm 0.34$ & $520 \pm 50$ & $147 \pm 4.6$ & $75.5 \pm 12.2$ & $27.4 \pm 5.1$ & $275 \pm 17$ & $\begin{array}{r}-63.3 \pm 0.6 \\
-\quad 1.6 \pm 0.4\end{array}$ \\
\hline $\begin{array}{l}\text { Krebs }+ \text { glucose } \\
13.9 \mathrm{~m} M / 1+\mathrm{Na}_{2} \mathrm{SO}_{4} 50 \mathrm{~m} M / 1\end{array}$ & $1.40 \pm 0.27$ & $258 \pm 69$ & $221 \pm 7.5$ & $25.3 \pm 6.4$ & $18.2 \pm 4.4$ & $234 \pm 33$ & $\begin{array}{l}-91.9 \pm 1.8 \\
-3.5 \pm 1.0\end{array}$ \\
\hline
\end{tabular}

a Glucose of the initial pool not found in perfusing and collected fluids at the end of experiments, 